\title{
DETERMINATION OF REFERENCE GENES FOR NORMALISATION OF GENE EXPRESSION STUDY OF Ganoderma-INFECTED OIL PALMS
}

\author{
LIYANA MOHD ZUHAR*; AHMAD ZAIRUN MADIHAH ${ }^{\star *}$; SITI AQLIMA AHMAD*; ZAMRI ZAINAL*; \\ ABU SEMAN IDRIS** and NOOR AZMI SHAHARUDDIN ${ }^{\ddagger \neq}$
}

\begin{abstract}
Basal stem rot (BSR) disease is a major threat to oil palm industry in Malaysia, caused by pathogenic fungus, Ganoderma boninense. Quantitative real-time polymerase chain reaction ( $q P C R$ ) has become a favourable method in quantification the levels of gene expression involved in disease development. In this study, 14 oil palm reference genes were tested for their suitability as reference genes for qPCR analyses using oil palm root taken from six-month old seedlings (nursery sample) and 15-year old mature palms (field sample). Only six reference genes were subjected to stability test via RefFinder. The GRAS and ACTIN genes were ranked as the best reference genes for nursery sample, whereas, GAPDH and GvHK genes for field samples. These reference genes were used in the qPCR analysis for accurate normalisation. Thus, results obtained in this study emphasise the importance of validating the stability of the reference gene and proving the credibility and reliability of RefFinder in determining the most stable reference genes in each specific experiment or biological setting used.
\end{abstract}

Keywords: RefFinder, normalisation, reference genes, oil palm (Elaeis guineensis Jacq.), Ganoderma boninense, quantitative real-time PCR (qPCR).

Date received: 2 May 2018; Sent for revision: 7 September 2018; Received in final form: 23 January 2019; Accepted: 27 September 2019.

\section{INTRODUCTION}

Oil palm (Elaeis guineensis Jacq.) is currently one of the most economically important plantation crops in Malaysia with 5.74 million hectares of cultivation area (MPOB, 2017; Nadzri and Ahmad, 2016).

\footnotetext{
* Department of Biochemistry, Faculty of Biotechnology and Molecular Science, Universiti Putra Malaysia, 43400 UPM Serdang, Selangor, Malaysia.

** Malaysian Palm Oil Board, 6 Persiaran Institusi, Bandar Baru Bangi, 43000 Kajang, Selangor, Malaysia.

\# School of Biosciences and Biotechnology, Faculty of Science and Technology, Universiti Kebangsaan Malaysia, 43600 Bangi, Selangor, Malaysia.

¥ Institute of Plantation Studies, Universiti Putra Malaysia, 43400 UPM Serdang, Selangor, Malaysia. E-mail: noorazmi@upm.edu.my
}

However, Malaysian oil palm cultivation suffers from the most devastating fungal disease known as basal stem rot (BSR), which is caused by Ganoderma boninense. Oil palm from different geographical origins has been reported to have different level of susceptibility towards G. boninense infection, which may be resulting from the genetic resistance of each palm (Durand-Gasselin et al., 2005; Idris et al., 2004). Thereby, several studies have been conducted to identify key genes and elucidate biological pathways involved in the disease development of oil palm (Tan et al., 2013; Tee et al., 2013; Yeoh et al., 2012; 2013).

Quantitative real-time polymerase chain reaction (qPCR) is an analytical technique that has the ability to detect and precisely quantify levels of gene expression by measuring relative small amount of messenger ribonucleic acid (mRNA) in 
cells (Sanders et al., 2014). The major advantage of $\mathrm{qPCR}$ is that the technique can analyse large number of samples rapidly with significantly high degree of sensitivity and specificity. Hence, this technique has become one of the most preferred methods to quantitatively determine the presence of the gene of interest in a cell population under specific conditions (Gadkar and Fillion, 2013). In qPCR assay, the expression level of target genes is determined by measuring the changes of expression across samples in different conditions (healthy and disease). However, gene expression assay is often prone to variations and errors associated with sampling methods, RNA preparations, reverse transcription and amplification efficiencies of the target genes across different samples in different conditions, which would cause variability and affecting the assay results (Vandesompele et al., 2002; Bustin, 2002; Andersen et al., 2004).

Normalisation of gene of interest with internal calibrator known as reference genes, which need to have constant expression levels across different sample experimental conditions or treatments, is essential to minimise variations and errors that may rise from the comparison of gene expression assay, as well as avoiding misrepresentation of the gene of interest expression fold. In oil palm, several stable reference genes have been reported, however, each of the reference gene has different stability in different species, varieties, tissues, developmental stages, organ, and under different experimental conditions (Chan et al., 2014; Xia et al., 2014; Yeap et al., 2014). Therefore, selection and validation of appropriate reference genes are essential in obtaining accurate results during qPCR analysis.

In common practices, the expression stability of the reference genes is evaluated and ranked using four major softwares, such as geNorm (Vandesomple et al., 2002), NormFinder (Andersen et al., 2004), BestKeeper (Pfaffl et al., 2004) and delta Ct method (Silver et al., 2006). Each of the software has equal capability in determining the stability of the tested reference genes. However, every program uses different mathematical calculation methods, causing the stability ranking of the genes to vary, hence, making it difficult to achieve a consensus of the most stable reference genes under a particular condition from all these softwares (Zhang et al., 2015).

A web-based integrated tool known as RefFinder (leonxie.esy.es/RefFinder/), which incorporates these four major program algorithms (geNorm, NormFinder, BestKeeper and delta Ct method), provides solution to overcome the different limitations of each computational algorithm by determining the stability of the reference genes based on the consensus ranking from all the programs. RefFinder enables the assessment of the most stable reference genes by balancing the reference genes ranking across these algorithms via calculating the geometric mean of the genes and determining the overall comprehensive stability value for each reference gene (Xie et al., 2012). RefFinder has been reported to successfully determine the most stable reference genes in different plants such as sugarcane (de Andrade et al., 2017) and tree peony (Li et al., 2016). Moreover, this program has been proven to generate reference gene stability ranks that are in agreement with geNorm, NormFinder, BestKeeper and delta CT method (De Spiegelaere et al., 2015). Thus, the objective of this study was to assess the most stable reference genes for qPCR analysis of six-month old oil palm seedlings (nursery sample) and 15-year old mature palms (field sample) under Ganoderma-infected condition using RefFinder program.

\section{MATERIALS AND METHODS}

\section{Selection of Reference Genes Candidate}

Fourteen oil palm reference genes that have shown stable expression across various oil palm tissues as reported by Chan et al. (2014), Xia et al. (2014), and Yeap et al. (2014) were selected. The details of the primers are shown in Table 1.

\section{Selection of Planting Materials}

The uniformity of the reference genes were validated using RNA samples extracted from roots of six-month old oil palm seedlings grown in the nursery and 15-year old mature palms grown in the field. The root samples were taken based on two different conditions: healthy samples (uninfected/ control) and samples infected with G. boninense (infected). The infected samples were selected based on visual external symptoms such as the wilting of leaves and the formation of fruiting body on the oil palm stem. For the nursery samples, both the healthy and infected root tissues were sampled from six-month old oil palm seedlings grown at MPOBUKM nursery, Bangi, Selangor in Malaysia. The inoculated palms were artificially inoculated with $G$. boninense for three months before the root samples were harvested at 12 weeks post inoculation (wpi). As for the field samples, the primary root tissues were sampled from 15-year old oil palm at two different locations; the healthy tissues were taken from oil palm plantation at Keratong, Pahang in Malaysia while the infected tissues were taken from oil palm plantation at Seberang Perak, Perak. The root tissues were cleaned with tap water and wiped using $70 \%$ ethanol to remove external contaminants from the samples. The samples were immediately frozen in liquid nitrogen and stored in $-80^{\circ} \mathrm{C}$ until further use. 


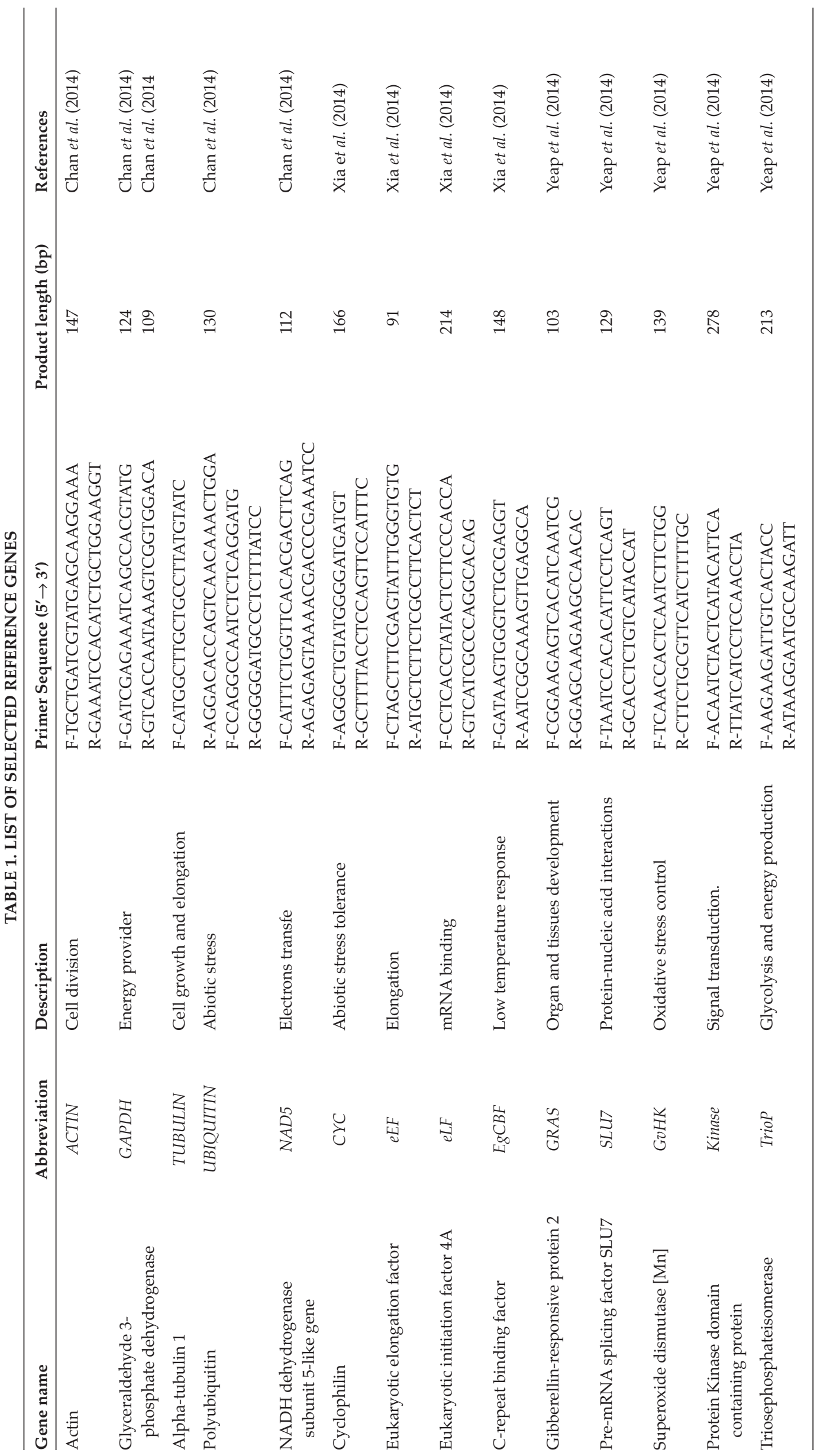


Total RNA Extraction, RNA Quality Assessment and First Strand cDNA

RNA from oil palm roots were extracted using cetyl trimetylammonium bromide (CTAB) protocol according to Zeng and Yang (2002), with some modifications. The extracted RNA was treated with DNase 1 using the RQ1 RNase-Free DNase Kit (Promega, Madison, WI, USA). The concentration and the quality of the total RNA were determined using NanoDrop® ND-1000 Analysis (Thermo Scientific, Wilmington DE). The RNA integrity was assessed on $1.5 \%(\mathrm{w} / \mathrm{v})$ agarose gel electrophoresis. First strand cDNA was synthesised from $2 \mu \mathrm{g}$ of total RNA in a $20 \mu \mathrm{l}$ of reaction volume using GoScript ${ }^{\mathrm{TM}}$ Reverse Transcription Kit (Promega, Madison, WI, USA) according to the manufacturer's protocol.

\section{Specificity Test Using PCR}

Fourteen candidate of reference genes were subjected to specificity evaluations. The PCR was carried out in $20 \mu \mathrm{l}$ reaction mixture containing $10 \times$ PCR buffer; $25 \mathrm{mM}$ of $\mathrm{MgCl}_{2} 10 \mathrm{mM}$ of dNTP mix;

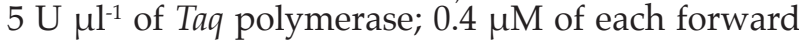
and reverse gene specific primers; $1.0 \mu \mathrm{l}$ of cDNA and $11.5 \mu \mathrm{l}$ of nuclease-free water. The mixture was run in Bio-RAD thermo cycler (Bio-Rad, USA) according to the following programs: 2 min initial denaturation at $95^{\circ} \mathrm{C}$; followed by 35 cycles of $1 \mathrm{~min}$ at $94^{\circ} \mathrm{C}, 30 \mathrm{~s}$ at $61^{\circ} \mathrm{C}, 1 \mathrm{~min}$ at $72^{\circ} \mathrm{C}$; a $5 \mathrm{~min}$ final extension at $72^{\circ} \mathrm{C}$ and hold at $15^{\circ} \mathrm{C}$. The amplicons were electrophorised in $1.5 \%$ agarose gel at $80 \mathrm{~V}$ constant for $60 \mathrm{~min}$, followed by ethidium bromide (EtBr) staining for $10 \mathrm{~min}$, destained in distilled water for $10 \mathrm{~min}$, and visualised the gel under UV light using Bioimaging System (UVP, USA). The specificity of the amplification product for each primer pair was determined by the production of a single product within the expected amplicon length. The primers that generated specific product were chosen for amplification efficiency test using qPCR.

\section{Efficiency Test of Primer Amplification via qPCR}

The efficiency of the primers amplification towards the root tissues from oil palm nursery and field samples was tested by constructing the primers standard curves using cDNA as template in four-fold dilution series: $100 \mathrm{ng}, 25 \mathrm{ng}, 6.25 \mathrm{ng}, 1.56 \mathrm{ng}$ and 0.39 ng corresponded to $10^{0}, 10^{-1}, 10^{-3}$ and $10^{-4}$, respectively, while the specificity of primers towards each of oil palm tissues was further confirmed from the melt curve analysis. The qPCR was carried out using SensiFast $^{\mathrm{TM}} \mathrm{SYBR}^{\circledR}$ No-ROX One-Step Master Mix Kit $(2 \times)$ (Bioline, USA) according to manufacturer's protocol and performed in triplicates. The primer efficiency test was carried out using Bio-RAD CFX96 Real-time PCR thermo cycler (Bio-Rad,
USA) with the cycling conditions as follows: $95^{\circ} \mathrm{C}$ of initial denaturation for $2 \mathrm{~min}, 40$ cycles of $95^{\circ} \mathrm{C}$ for $5 \mathrm{~s}$ and $61^{\circ} \mathrm{C}$ for $30 \mathrm{~s}$; followed by dissociation curve programmed at $65^{\circ} \mathrm{C}$ at $5 \mathrm{~s}$ and $95^{\circ} \mathrm{C}$ for $5 \mathrm{~s}$ with a heating rate increment of $0.1^{\circ} \mathrm{C}$ per $1 \mathrm{~s}$. Two negative controls were included; no reverse transcriptase (NRT) and non-template control (NTC). The result of the primer efficiency was analysed by using the Bio-Rad CFX Manager V3.0 software and the PCR amplification efficiency (E) was calculated based on the slope data of the primer pair's standard curve with the following formula: $\mathrm{E}=\left[10^{(-1 / \text { slope })}-1\right] \times 100 \%$ (Pfaffl, 2001). The primers pair that amplified with efficiencies ranging from $90 \%-110 \%$, had $\mathrm{R}^{2}$ values greater than 0.98, slope value between -3.6 and -3.1, and produced single peak from melting curve analysis were selected for stability validation assay.

\section{Stability Ranking of Reference Genes Using RefFinder}

The expression stability of the reference genes were evaluated using cDNA of healthy and infected oil palm tissues as a template. The expression levels of the reference gene candidates were assessed based on the number of amplification cycles needed to reach fixed cycle threshold $(\mathrm{Cq})$ during exponential phase. The raw $\mathrm{Cq}$ values of all reference genes in root tissues at different conditions (infected and control) were subjected to expression stability evaluations using the RefFinder program (leonxie. esy.es/RefFinder/) (Xie et al., 2012). Two reference genes ranked as the most stably expressed genes were subsequently used for normalisation in the expression profiling studies of the gene of interest.

\section{RESULTS}

\section{Primers Specificity}

Fourteen DNA primers pair designed for the candidate reference genes were tested onto root cDNA of healthy and Ganoderma-infected oil palm using PCR. The result showed that out of 14 reference genes, only eight of the genes, namely ACTIN, eEF, TUBULIN, eLF, GRAS, GvHK, GADPH, and UBIQUITIN were able to amplify an intact single band product (Figure 1). The formation of a single band indicates that these DNA primers were specific in amplifying target regions from the root CDNA. However, the result also revealed that primers for $E g C B F, N A D 5, C Y C$ and SLU7 reference genes produced multiple bands, while primers for TrioP and Kinase genes were unable to amplify desired product from the template. The DNA primers that failed to amplify a single product were subjected to optimisation by amplifying the genes at several annealing temperatures ranging from 


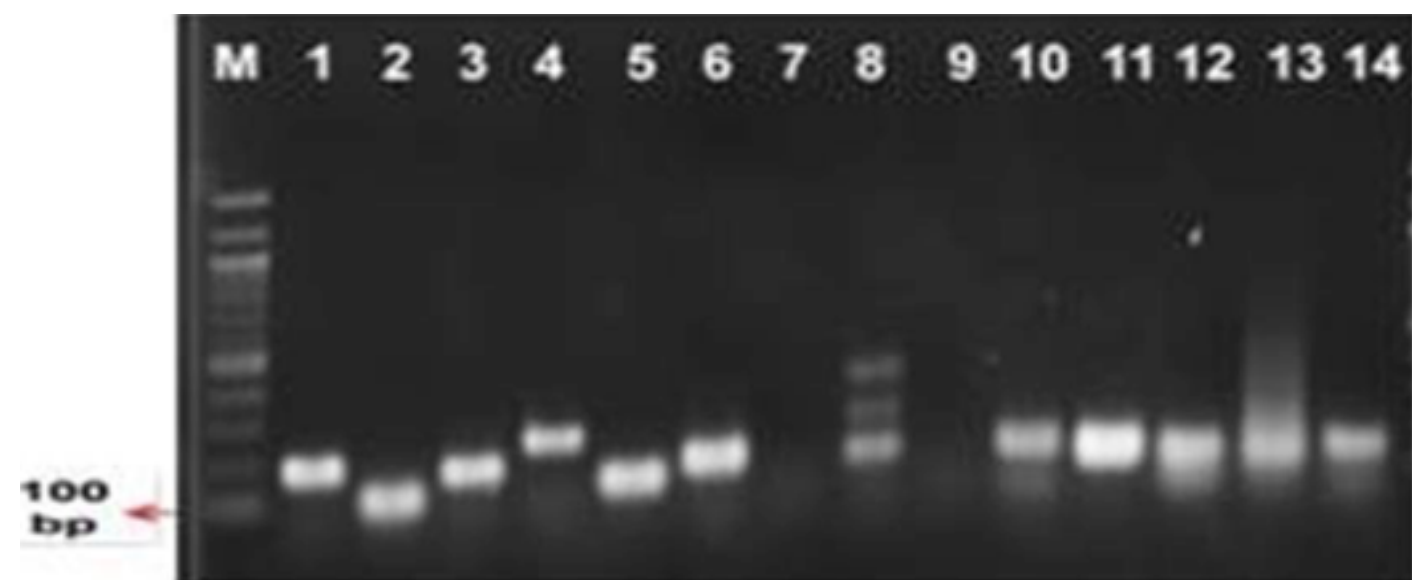

Figure 1. Polymerase chain reaction (PCR) amplification of the reference genes on oil palm root analysed on 1.5\% (w/v) agarose gel. M: GeneRuler 100 bp (Fermentas, USA), Lane 1: ACTIN, Lane 2: eEF, Lane 3: TUBULIN, Lane 4: eLF, Lane 5: GRAS, Lane 6: GvHK, Lane 7: KINASE, Lane 8: SLU7, Lane 9: TrioP, Lane 10: CYC, Lane 11: GADPH, Lene 12: EgCBF, Lane 13: UBIQUITIN, Lane 14: NAD5.

$55^{\circ} \mathrm{C}$ to $65^{\circ} \mathrm{C}$ to determine the optimal temperature (Fraga et al., 2008). Nevertheless, the results obtained remained the same, indicating that the primers were unspecific toward the samples used in this study. Therefore, only the DNA primers that amplified intact single bands from the root samples were subjected to qPCR assay.

\section{Amplification Efficiency Test}

All eight DNA primer pairs of the reference genes (ACTIN, eEF, TUBULIN, eLF, GRAS, GvHK, GADPH, and UBIQUITIN) that could amplify a single PCR product were further evaluated via $\mathrm{qPCR}$ for the specificity and efficiency tests using melt curve and standard curve analyses before subjected to stability validation assay. The amplification efficiency (E) refers to the efficiency of the reaction in which $E$-value of $100 \%$ indicates that specific target product is amplified in each PCR cycle of the exponential phase (Fraga et al., 2008). The correlation coefficient $\left(R^{2}\right)$ value reflects the uniformity and a better fitting of the technical replicate for each cDNA serial dilution in generating experimental data in the standard curve, while the slope generated from the standard curve reflects the PCR amplification efficiency and a negative slope value indicates that the amplification efficiencies are comparable. According to the international MIQE guideline in conducting qPCR assay, the acceptable primer amplification efficiency is between $90 \%$ and $110 \%$ with good correlation coefficient value $\left(R^{2}>0.98\right)$, slope value ranges from -3.6 to -3.1 and generate single peak in melt curve analysis (Bustin et al., 2009).

Our result showed that six reference genes ACTIN, GAPDH, TUBULIN, eEF, GvHK, and GRAS generated single peak in melt curve analysis as depicted in Figure 2, confirming that the primer pairs amplified specific products. Moreover, these genes also have amplification efficiency (Table 2) that ranges between $95.3 \%$ to $110.2 \%$ with $\mathrm{R}^{2}$ value of 0.989 to 0.997 and slope value ranges -3.440 to -3.157 , corresponded to the standard optimal result listed in MIQE guideline (Bustin et al., 2009). However, as for the remaining two reference gene candidates, eLF and UBIQUITIN showed the production of nonspecific products in both melt curve and standard curve analyses.

Standard curve of eLF reference gene showed the amplification efficiency was greater than $100 \%$, which was thought to be influenced by the formation of two target products at temperature of $85^{\circ} \mathrm{C}$ and $89.5^{\circ} \mathrm{C}$ in the reaction (Fraga et al., 2008). Meanwhile, for UBIQUITIN gene, a formation of primer dimer was observed at temperature between $75^{\circ} \mathrm{C}$ to $79^{\circ} \mathrm{C}$, thus affecting the $\mathrm{R}^{2}$ and forming positive slope, indicating that the amplification efficiency of UBIQUITIN is incomparable. Both primer sets for eLF and UBIQUITIN were optimised by adjusting the annealing temperature between $60^{\circ} \mathrm{C}$ to $70^{\circ} \mathrm{C}$ to increase the primer specificity and eliminate non-specific products. However, after optimisation step, the formation of non-specific products was still observed. The results indicated that the eLF and UBIQUITIN primer sets were unspecific in amplifying the targeted product from root tissues.

\section{Reference Genes Stability Test via RefFinder}

Six candidate reference genes (ACTIN, GAPDH, TUBULIN, eEF, GvHK, and GRAS) with efficient amplification were subjected to qPCR analysis using samples from the nursery and field at different treatment conditions (healthy and disease). The $\mathrm{Cq}$ values for each reference gene from all the root samples under different treatment conditions were calculated to determine the gene stability 

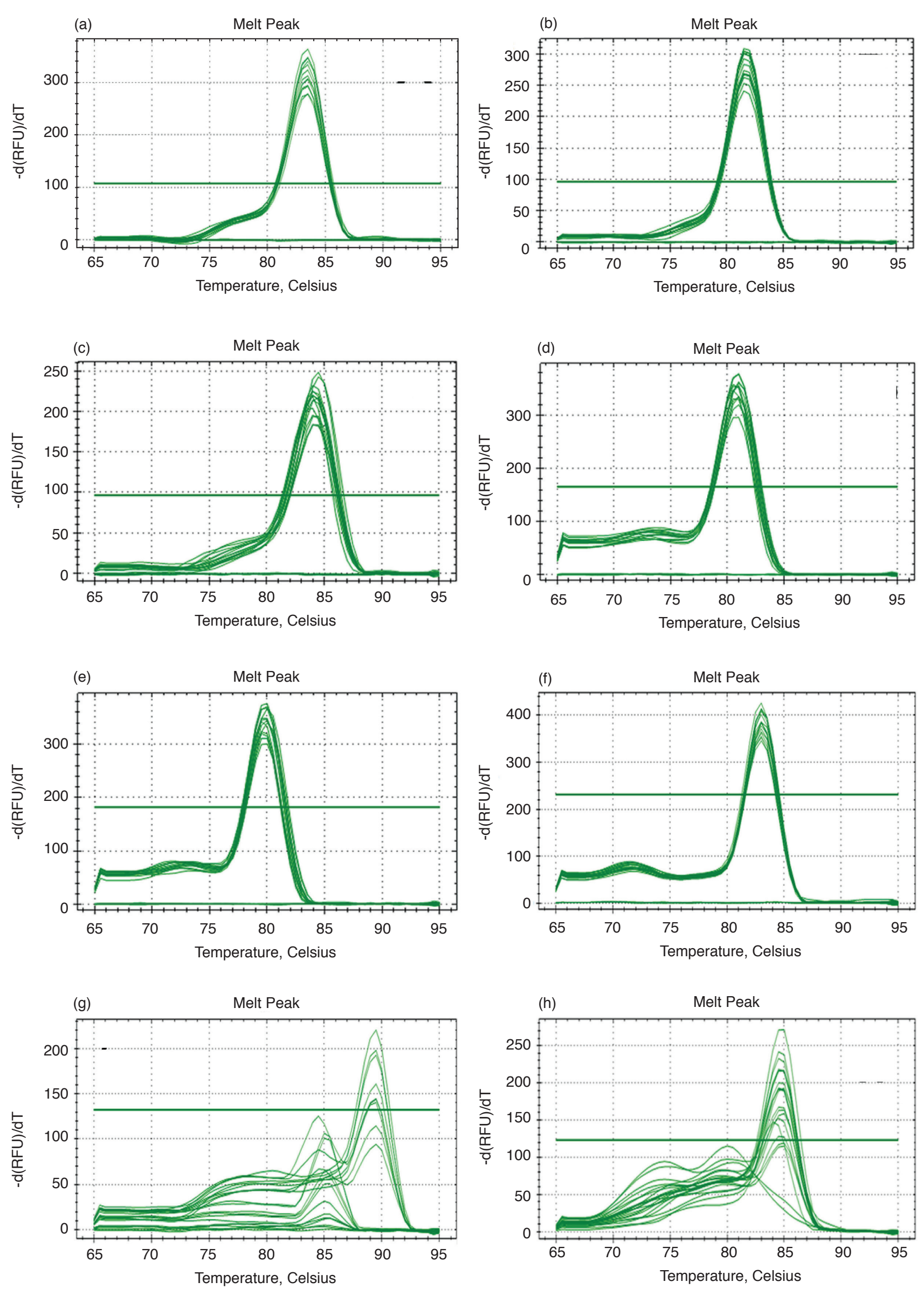

Figure 2. Melt curve analysis of the reference genes on oil palm root (a) ACTIN, (b) GAPDH, (c) TUBULIN, (d) eEF, (e) GRAS, $(f)$ GvHK, $(g)$ eLF and $(h)$ UBIQUITIN. 
TABLE 2. SUMMARY OF PRIMER AMPLIFICATION EFFICIENCY TEST OF THE REFERENCE GENES FROM OIL PALM ROOT

\begin{tabular}{lcccc}
\hline $\begin{array}{l}\text { Gene } \\
\text { name }\end{array}$ & $\begin{array}{c}\text { Efficiency } \\
(\mathbf{E}, \boldsymbol{\%})\end{array}$ & $\begin{array}{c}\text { Correlation } \\
\text { coefficient } \\
\left(\mathbf{R}^{2}\right)\end{array}$ & Slope & $\begin{array}{c}\text { Melt } \\
\text { temperature } \\
\text { Tm }\left({ }^{\circ} \mathbf{C}\right)\end{array}$ \\
\hline ACTIN & 107.4 & 0.989 & -3.157 & 83.5 \\
GAPDH & 99.1 & 0.996 & -3.345 & 81.5 \\
TUBULIN & 110.2 & 0.997 & -3.079 & 84.5 \\
eEF & 95.3 & 0.990 & -3.440 & 81.0 \\
GRAS & 105.0 & 0.994 & -3.209 & 80.0 \\
GvHK & 104.8 & 0.995 & -3.212 & 83.0 \\
eLF & 144.0 & 0.888 & -2.581 & $85.0 / 89.5$ \\
UBIQUITIN & 97.2 & 0.320 & 0.641 & $77.0 / 84.5$ \\
\hline
\end{tabular}

using RefFinder. Based on the RefFinder result, the program ranked different reference genes for nursery and field samples as the most stable genes across different statistical algorithms as shown in Table 3.

For six-month old seedlings (nursery sample) GRAS was ranked as the most stable reference gene with stability value of 1.000 followed by ACTIN as the second most stable gene with stability value of 1.682 among the six reference gene candidates. The least stable reference gene was $e E F$ with stability value of 6.000. The stability of the genes was arranged in a descending order as GRAS $>A C T I N>G v H K>$ GAPDH $>$ TUBULIN $>e E F$. Moreover, the stability ranking results generated from all four major algorithms (geNorm, NormFinder, BestKeeper and delta $\mathrm{Ct}$ method) revealed that all programs had ranked GRAS as the most stable reference genes and $e E F$ as the least stable reference genes.

As for the mature palms (15-year old field samples), RefFinder ranked GAPDH as the overall most stable gene with stability value of 1.414 followed by $\mathrm{GvHK}$ with stability value of 1.565 . The least stable reference gene was $e E F$ with stability value of 5.733. The stability of the genes was arranged in a descending order as GAPDH $>G v H K>G R A S>$ $A C T I N>$ TUBULIN $>e E F$. Slight differences in the ranking of the most stable genes were noticed among the four programs, where geNorm and NormFinder ranked GAPDH as the most stable reference gene followed by $G v H K$, while delta $\mathrm{Ct}$ method ranked $\mathrm{GvHK}$ as the most stable gene followed by GAPDH, and BestKeeper ranked GAPDH as the second stable reference gene whereas $G v H K$ as the third stable reference gene. Meanwhile, geNorm, NormFinder, and delta $\mathrm{Ct}$ method ranked $e E F$ as the least stable reference gene whereas BestKeeper ranked $e E F$ as the second least stable reference gene and TUBULIN as the least stable reference gene.

\section{DISCUSSION}

BSR caused by Ganoderma boninense is the most economically disastrous disease to oil palm industry in Malaysia. In order to understand the molecular basis involved in plant response towards the fungal infection, studies with qPCR have been widely conducted for characterising gene expression patterns of oil palm defence mechanism towards the

TABLE 3. EXPRESSION STABILITY VALUE OF THE REFERENCE GENES FROM OIL PALM NURSERY ROOT IN ALL CONDITIONS AND THEIR STABILITY RANKING FROM DIFFERENT SOFTWARE ALGORITHMS INCORPORATED BY REFFINDER

\begin{tabular}{|c|c|c|c|c|c|c|c|c|c|c|}
\hline \multirow[t]{2}{*}{$\begin{array}{l}\text { Reference } \\
\text { genes }\end{array}$} & \multicolumn{2}{|c|}{$\begin{array}{l}\text { RefFinder geomean } \\
\text { ranking value } \\
\end{array}$} & \multicolumn{2}{|c|}{ geNorm } & \multicolumn{2}{|c|}{ NormFinder } & \multicolumn{2}{|c|}{ BestKeeper } & \multicolumn{2}{|c|}{ Delta CT method } \\
\hline & Stability & Rank & Stability & Rank & Stability & Rank & Stability & Rank & Stability & Rank \\
\hline \multicolumn{11}{|c|}{ Oil palm seedings root from nursery } \\
\hline GRAS & 1.000 & 1 & 0.133 & $1^{*}$ & 0.379 & 1 & 0.244 & 1 & 1.230 & 1 \\
\hline ACTIN & 1.682 & 2 & 0.133 & $1^{*}$ & 0.418 & 2 & 0.267 & 2 & 1.263 & 2 \\
\hline $\mathrm{GvHK}$ & 3.224 & 3 & 0.340 & 2 & 0.485 & 3 & 0.472 & 3 & 1.316 & 3 \\
\hline GAPDH & 3.722 & 4 & 0.407 & 3 & 1.008 & 4 & 0.509 & 4 & 1.419 & 4 \\
\hline TUBULIN & 5.000 & 5 & 1.208 & 4 & 2.126 & 5 & 1.753 & 5 & 2.495 & 5 \\
\hline$e E F$ & 6.000 & 6 & 1.769 & 5 & 2.677 & 6 & 1.991 & 6 & 2.892 & 6 \\
\hline \multicolumn{11}{|c|}{ Mature oil palm root from field } \\
\hline GAPDH & 1.414 & 1 & 0.706 & $1^{*}$ & 1.076 & 1 & 1.713 & 2 & 1.923 & 2 \\
\hline $\mathrm{GvHK}$ & 1.565 & 2 & 0.706 & $1^{*}$ & 1.131 & 2 & 1.883 & 3 & 1.916 & 1 \\
\hline GRAS & 3.224 & 3 & 0.963 & 2 & 1.217 & 3 & 2.156 & 4 & 2.034 & 3 \\
\hline ACTIN & 3.344 & 4 & 1.948 & 4 & 2.066 & 5 & 0.404 & 1 & 2.630 & 5 \\
\hline TUBULIN & 4.427 & 5 & 1.550 & 3 & 1.620 & 4 & 2.842 & 6 & 2.371 & 4 \\
\hline$e E F$ & 5.733 & 6 & 2.326 & 5 & 2.733 & 6 & 2.552 & 5 & 3.080 & 6 \\
\hline
\end{tabular}

Note: *geNorm algorithm evaluates the expression stability value (M) of each reference gene based on mean pairwise variation between selected candidate reference genes. Therefore, the software will generate the average ratio of two best stable genes expression levels that are sufficient to be normalised in our study (Vandesompele et al., 2002). 
fungal disease (Tan et al., 2013; Tee et al., 2013; Yeoh et al., 2012; 2013).

The accuracy of the relative quantification of gene expression levels using qPCR is highly dependent on the normalisation of the target genes with reference genes to minimise variation that arise during sample preparation and reaction. Theoretically, a good reference gene will express constantly with a minimal change of expression and its expression is independent regardless of any experimental condition and parameters. However, some studies revealed that oil palm reference genes expression are prone to undergo stability changes depending on the plant experimental conditions (Chan et al., 2014; Xia et al., 2014; Yeap et al., 2014). Hence, preliminary evaluation and validation must be conducted in each experimental background to determine most stable reference genes to be used. In addition, it is recommended to use at least two reference genes for optimum normalisation of nonbiological sample-to-sample variation introduced during gene expression analysis to avoid biases and misinterpretation of data that will yield inaccurate results (Nicot et al., 2005).

Herein, the stability in reference gene expressions was evaluated on oil palm root seedlings and mature palms under two different conditions, healthy samples (uninfected/control) and samples infected with G. boninense (infected) via RefFinder. The RefFinder incorporates the available major computational algorithms (geNorm, NormFinder, Bestkeeper and delta Ct method) that will allocate appropriate weight to each reference gene and calculates the geometric mean of the genes weights for determining the stability final ranking, named comprehensive ranking (Xie et al., 2012). The selection of the most stable reference genes depends on the finding of reference genes with lowest Geomean value (de Andrade et al., 2017).

In the present work, RefFinder analysis had ranked different set of most stable reference genes across different statistical algorithms for the nursery and field samples. GRAS and ACTIN genes are the best reference genes to be used in gene expression studies of oil palm seedlings (sixmonth old) whereas GAPDH and GvHK are the best reference genes for mature palms (Figure 3). Meanwhile, TUBULIN and $e E F$ were ranked as the least stable reference genes by RefFinder across different statistical algorithms for both nursery and field samples. By comparing the stability ranking results generated from the four major algorithms, i.e. geNorm, NormFinder, BestKeeper and delta $\mathrm{Ct}$ method, all programs were in consensus to rank GRAS and ACTIN as the most stable reference genes for nursery samples, indicating high correlation among these comparative programs. However, in mature palm samples, ranking was slightly different among the four programs. These differences may have probably been affected by the sampling
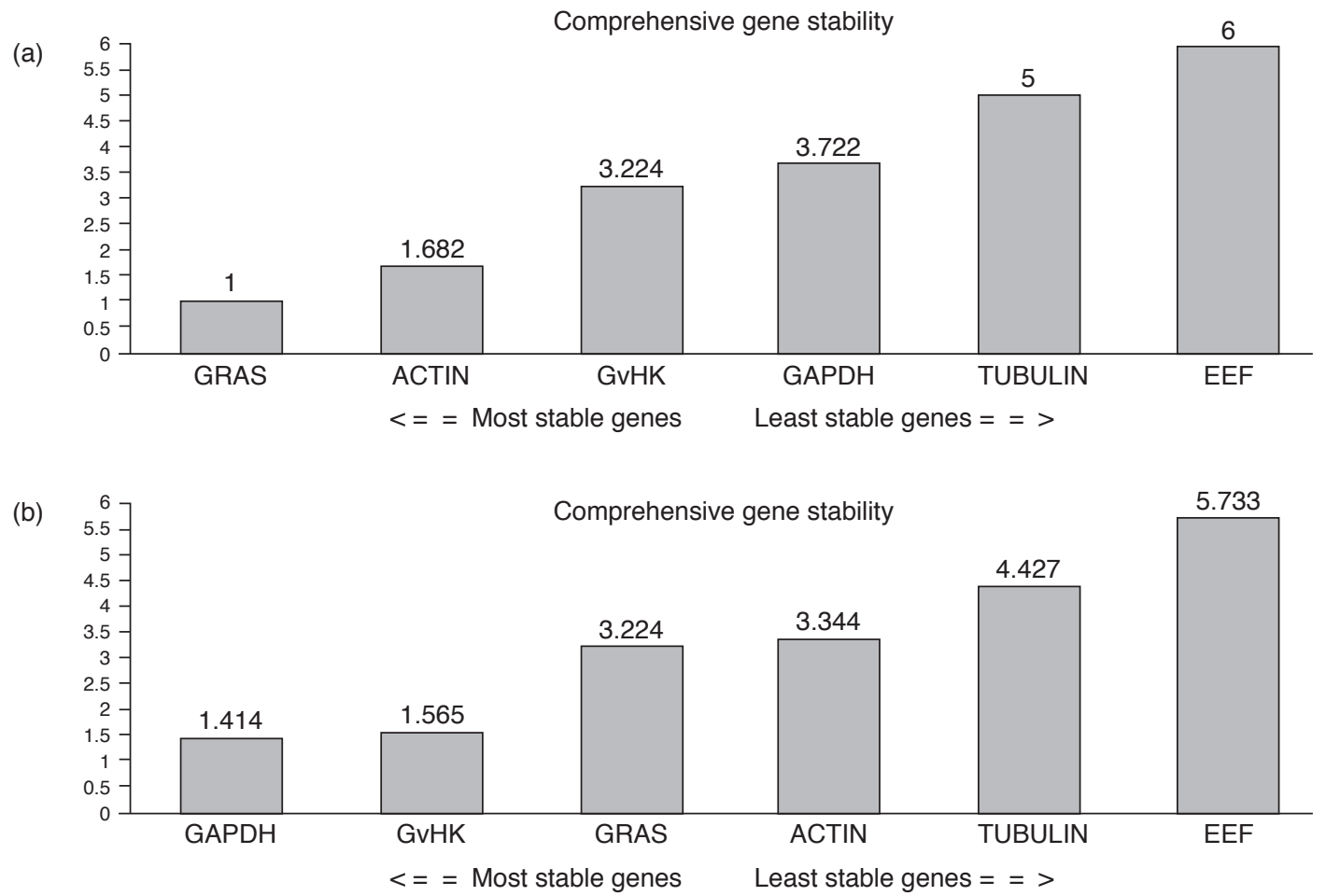

Figure 3. Expression stability of the reference genes in all conditions (healthy and disease palm) and their stability ranking generated by RefFinder. (a) Value of reference genes from nursery root with GRAS and ACTIN ranked as the most stable reference genes and (b) value of reference genes from field root with $\mathrm{GAPDH}$ and $\mathrm{GvHK}$ ranked as the most stable reference genes. 
method; where each of the field sample collected for this study has different exposures toward variety of external abiotic stresses (i.e., soil composition, water retention or rainfall condition, sunlight saturation, fertiliser, etc.), and biotic stresses (i.e., insect, fungi, etc.) depending on their location in the plantation, in which these stresses also influence and contribute to the expression of the reference genes in oil palm (Yang et al., 2011; Chan et al., 2014; Ho et al., 2018). The consensus ranking of reference genes calculated by RefFinder across all programs in both nursery and field samples showed the credibility and reliability of this program in determining the best reference genes to be used in normalisation of gene expression analysis.

Our results have shown that different reference genes were suggested for gene expression analysis at different stages of oil palm's development. The difference might be due to the age of oil palm used in this study where the root samples were taken from six-month old oil palm seedlings (nursery) and 15year old mature palms (field). It has been reported that reference genes have different expression consistency across plant tissues under different developmental stages and different experimental or stress conditions (Chan et al., 2014; Xia et al., 2014; Yeap et al., 2014). Several studies have assessed the stability of candidate reference genes in oil palm nursery samples, for example, Kwan et al. (2016) evaluated the stability of reference genes in threemonth old oil palm seedling root tissues during Ganoderma infection, suggesting NAD (NADH dehydrogenase subunit 5-like), Ubiquitin and MSD (manganese superoxide dismutase) genes as the most stable. However, both NAD5 and UBIQUITIN in our study exhibited unspecific amplification in root tissues during Ganoderma infection condition. Meanwhile, Yeap et al. (2014) reported the GRAS gene as the best reference gene in root vegetative tissues and reproductive tissues of six-month old oil palm seedling, in which consistent with our result of GRAS gene that was ranked as the most stable reference gene in the nursery samples. Hence, this explains GRAS gene has stable expression in six-month old oil palm seedlings (Yeap et al., 2014). As for field samples, GAPDH that was ranked as the most stable reference gene was proven to be the most stable gene to be used for plantation samples that are exposed to variety of external stresses as it did not show any variation between different tissues under different experimental condition (Kozera and Rapacz, 2013).

Based from the RefFinder analysis, it was suggested to use two of the most stable reference genes (with lowest Geomean value) for qPCR assay normalisation in oil palm Ganoderma-infected root nursery and field samples as the accuracy of qPCR results will improve by the increasing number of reference genes used in a study (Nicot et al., 2005;
Lim et al., 2014). Moreover, the different set of stable reference genes generated by RefFinder for both oil palm nursery and field samples indicates that reference genes need to be validated before they can be used in normalisation of gene expression study, even though the samples are from the same plant tissues since the stability of each reference gene differs greatly depending on the plant ages, developmental stages or experimental conditions.

\section{CONCLUSION}

RefFinder is proven to be a suitable web-based program in determining the most stable reference genes for normalisation of qPCR analysis on oil palm samples of different ages and growth conditions. Consensus ranked generated by the RefFinder showed the most stable reference genes for both of the oil palm Ganoderma-infected root samples; GRAS and GAPDH were the best reference genes for nursery samples and field samples, respectively. Moreover, the stability ranking results obtained in this study highlighted the importance of validating the stability of the reference genes in each specific experiment or biological setting used; even the samples are of the same plant tissues.

\section{ACKNOWLEDGEMENT}

The authors would like to thank the DirectorGeneral of MPOB for the permission to publish this article. The authors would also like to acknowledge Ganoderma and Disease Research for Oil Palm (GanoDROP) Unit, Biology Division, MPOB, for providing knowledge and assistance throughout the study.

\section{REFERENCES}

Andersen, C L; Jensen, J L and Orntoft, T F (2004). Normalization of real-time quantitative reverse transcription-PCR data: Model-based variance estimation to identify genes suited for normalization, applied to bladder and colon cancer data sets. Cancer Res., 64: 5245-5250.

Bustin, S A; Benes, V; Garson, J A; Hellemans, J; Huggett, J; Kubista, M; Mueller, R; Nolan, T; Pfaffl, M W; Shipley, G L; Vandesompele, J and Wittwer, C T (2009). The MIQE guidelines: Minimum information for publication of quantitative real-time PCR experiments. Clin. Chem., 55(4): 611-622.

Bustin, S A (2002). Quantification of mRNA using real-time reverse transcription PCR (RT-PCR): Trends and problems. J. Mol. Endocrinol., 29: 23-29. 
Chan, P L; Rose, R J; Abdul, M A; Zainal, Z; Low, E T; Ooi, L C; Ooi, S E; Yahya, S and Singh, R (2014). Evaluation of reference genes for quantitative real-time PCR in oil palm elite planting materials propagated by tissue culture. PLoS ONE, 9: e99774.

DeAndrade, L M; Dos Santos Brito, M; Peixoto Junior, R F; Marchiori, P E R; Nóbile, P M; Martins, A P B; Ribeiro, R V and Creste, S (2017). Reference genes for normalization of qPCR assays in sugarcane plants under water deficit. Plant Methods, 13: 28-36.

De Spiegelaere, W; Dern-Wieloch, J; Weigel, R; Schumacher, V; Schorle, H; Nettersheim, D; Bergmann, M; Brehm, R; Kliesch, S; Vandekerckhove, L and Fink, C (2015). Reference gene validation for RT-qPCR, a note on different available software packages. PLOS ONE, 10(3): e0122515.

Durand-Gasselin, T; Asmady, H; Flori, A; Jacquemard, J C; Hayun, Z; Breton, F and De Franqueville, H (2005). Possible sources of genetic resistance in oil palm (Elaeis guineensis Jacq.) to basal stem rot caused by Ganoderma boninense - Prospects for future breeding. Mycopathologia, 159: 93-100.

Fraga, D; Meulia, T and Fenster, S (2008). Realtime PCR. Current Protocols Essential Laboratory Techniques. Wiley Online Libraries. p. 10.3.1-10.3.40. DOI: 10.1002 / $9780470089941 . e t 1003 s 08$.

Gadkar, V J and Filion, M (2013). Quantitative real-time polymerase chain reaction for tracking microbial gene expression in complex environmental matrices. Curr. Issues in Mol. Biol., 15: 45-58.

Ho, C L; Tan, Y C; Yeoh, K A; Lee, W K; Ghazali, A K; Yee, W Y and Hoh, C C (2018). Transcriptional response of oil palm (Elaeis guineensis Jacq.) inoculated simultaneously with both Ganoderma boninense and Trichoderma harzianum. Plant Gene, 13: 56-63.

Idris, A S; Kushairi, A; Ismail, S and Ariffin, D (2004). Selection of partial resistance in oil palm progenies to Ganoderma basal stem rot. J. Oil Palm Res. Vol. 16: 12-18.

Kozera, B and Rapacz, M (2013). Reference genes in real-time PCR. J. Appl. Genet., 54: 391-406.

Kwan, Y M; Meon, S; Ho, C 1 and Wong, M Y (2016). Selection of reference genes for quantitative realtime PCR normalization in Ganoderma-infected oil palm (Elaeis guineensis) seedlings. Australas. Plant Path., 45(3): 261-268.

Li, J; Han, J; Hu, Y and Yang, J (2016). Selection of reference genes for quantitative real-time PCR during flower development in tree peony (Paeonia suffruticosa Andr.). Front. Plant Sci., 7: 516-525.

Lim, F H; Iskandar, N F; Omar, A R; Idris A S; Ghulam, K A P; Ho, C 1 and Shaharuddin, N A (2014). Isolation and election of reference genes for Ganoderma boninense gene expression study using quantitative real-time PCR (qPCR). J. Oil Palm Res. Vol. 26(2): 170-181.

MPOB (2017). Oil palm planted area. http: / / bepi. mpob.gov.my / images / area/2016/ Area_summary. pdf

Nadzri, M M M and Ahmad, A (2016). Roller picker robot (ROPICOT 1.0) for loose fruit collection system. ARPN J. Engineering and Applied Sciences, 11(14): 8983-8986.

Nicot, N; Hausman, J F; Hoffmann, L and Evers, D (2005). Housekeeping gene selection for real-time RT-PCR normalization in potato during biotic and abiotic stress. J. Exp. Bot., 56: 2907-2914.

Pfaffl, M; Tichopad, A; Prgomet, C and Neuvians, T P (2004). Determination of stable housekeeping genes, differentially regulated target genes and sample integrity: BestKeeper-Excel-based tool using pair-wise correlations. Biotechnol. Lett., 26: 509-515.

Pfaffl, M W (2001). A new mathematical model for relative quantification in real-time RT-PCR. Nucleic Acids Res., 29(9): e45.

Sanders, R; Mason, D J; Foy, C A and Huggett, J F (2014). Considerations for accurate gene expression measurement by reverse transcription quantitative PCR when analyzing clinical samples. Anal. Bioanal. Chem., 406(26): 6471-6483. DOI: 10.1007/ s00216-0147857-x.

Silver, N; Best, S; Jiang, J and Thein, S L (2006). Selection of housekeeping genes for gene expression studies in human reticulocytes using real-time PCR. BMC Mol. Biol., 7: 33.

Tan, Y C; Yeoh, K A; Wong, M Y and Ho, C L (2013). Expression profiles of putative defence-related proteins in oil palm (Elaeis guineensis) colonised by Ganoderma boninense. J. Plant Physiol., 170: 1455-1460.

Tee, S S; Tan, Y C; Abdullah, F; Ong-Abdullah, M and Ho, C L (2013). Transcriptome of oil palm (Elaeis guineensis Jacq.) roots treated with Ganoderma boninense. Tree Genet. Genomes, 9: 377-386.

Vandesompele, J; De Preter, K; Pattyn, F; Poppe, B; Van Roy, N; De Paepe, A and Speleman, F (2002). Accurate normalization of real-time quantitative 
RT-PCR data by geometric averaging of multiple internal control genes. Genome Biol., 3(7): 0034.10034.11.

Xia, W; Mason, A S; Xiao, Y; Liu, Z; Yang, Y; Lei, X; Wu, X; Ma, Z and Peng, M (2014). Analysis of multiple transcriptomes of the African oil palm (Elaeis guineensis) to identify reference genes for RTqPCR. J. Biotechnol., 184: 63-73.

Xie, F L; Xiao, P X; Chen, D L; Xu, L and Zhang, B H (2012). miRDeepFinder: A miRNA analysis tool for deep sequencing of plant small RNAs. Plant Mol. Biol., 80: 75-84.

Yang, X S; Wu, J; Ziegler, T E; Yang, X; Zayed, A; Rajani, M S; Zhou, D; Basra, A S; Schachtman, D P; Peng, M; Armstrong, C L; Caldo, R A; Morrell, J A; Lacy, M and Staub, J M (2011). Gene expression biomarkers provide sensitive indicators of 6 nitrogen status in maize. Plant Physiol., 157(4): 1841-1852.

Yeap, W C; Loo, JM; Wong, Y C and Kulaveerasingam, $H$ (2014). Evaluation of suitable reference genes for qRT-PCR gene expression normalization in reproductive, vegetative tissues and during fruit development in oil palm. Plant Cell Tiss. Organ Cult, 116 (1): 55-66.

Yeoh, K A; Othman, A; Meon, S; Abdullah, F and Ho, C L (2013). Sequence analysis and gene expression of putative oil palm chitinase and chitinase-like proteins in response to colonization of Ganoderma boninense and Trichoderma harzianum. Mol. Biol. Rep., 40: 147-158.

Yeoh, KA; Othman, A; Meon, S; Abdullah, F and Ho, C L (2012). Sequence analysis and gene expression of putative exo- and endo-glucanases from oil palm (Elaeis guineensis) during fungal infection. J. Plant Physiol., 169: 1565-1570.

Zhang, S; An, S; Li, Z; Wu, F; Yang, Q; Liu, Y; Cao, J; Zhang, H; Zhang, Q and Liu, X (2015). Identification and validation of reference genes for normalization of gene expression analysis using qRT-PCR in Helicoverpa armigera (Lepidoptera: Noctuidae). Gene, 555(2): 393-402.

Zeng, Y and Yang, T (2002). RNA isolation from highly viscous samples rich in polyphenols and polysaccharides. Plant Molecular Biology Reporter, 20: 417a-417e. 